\title{
Recent developments and future prospects for encapsulation of organic solar cells
}

\author{
S.K. Jha* and Sanchit Gupta ${ }^{\#}$ \\ Division of Instrumentation and Control Engineering, \\ Netaji Subhas Institute of Technology, New Delhi, India \\ Email:*jhask271@gmail.com; \# gsanchit1995@gmail.com
}

The Organic solar cell (OSC) or commonly known as an organic photo voltaic has many advantages over the conventionally used silicon junction solar cells like flexibility, lower processing costs and a lesser adverse effect on the environment. But it suffers from two major drawbacks. It has a lower power conversion efficiency and a shorter lifetime. The active layer of the cell (Figure 1) degenerates in the presence of UV (ultra violet), moisture and oxygen. Thus to protect the cell from degradation, the cell is coated with some chemical material. This process is called encapsulation. The material used for encapsulation is called an encapsulant. It protects the cell against the ingress of oxygen, moisture and air. It also increases the lifetime and efficiency of the cell. Therefore, selection of the appropriate material for encapsulation of the solar cell is of utmost importance.

The encapsulation material should ideally be impermeable to oxygen and moisture as both corrodes the active layer of the cell. The acceptable rates for transmission through the encapsulant being less than $10^{-6} \mathrm{~g} / \mathrm{m}^{2} /$ day for moisture and $10^{-5} \mathrm{cc} / \mathrm{m}^{2} /$ day $/$ atm for oxygen. The other properties required for an encapsulation material are flexibility, low gas permeability and stability. The encapsulation material should also be easy to process with the manufacturing of the cell.

Three different materials were compared based on their Water Vapour Transmission Rates (WVTR) and other properties. Coating a mixture of two organic polymers PEMA poly (ethylene-co-methacrylic acid) and $\mathrm{EVOH}$ (ethylene vinyl alcohol) showed a WVTR of $10^{-}$ ${ }^{4} \mathrm{~g} / \mathrm{m}^{2} /$ day, which is much more than the maximum acceptable limit. Further, an inorganic material $\mathrm{Al}_{2} \mathrm{O}_{3}$ was used as an encapsulant and the WVTR was found out to be $1.7 * 10^{-5} \mathrm{~g} / \mathrm{m}^{2} /$ day. Another material consisting an alternate coating of inorganic material $\mathrm{SiN}_{\mathrm{X}}$ and $\mathrm{SiO}_{\mathrm{X}}$ with organic layers of PMMA or parylene between them and the WVTR was found out to be $6^{*} 10^{-6} \mathrm{~g} / \mathrm{m}^{2} /$ day which is within the maximum permissible limits. It also showed the properties very close to the ideal properties required for an encapsulant.

Inorganic materials offer high resistance to the permeation of gases and moisture but are less flexible and brittle. On the other hand, organic materials offer a lower resistance and higher flexibility. So an encapsulant containing a mixture of both organic and inorganic material can be considered as a good alternative for encapsulation of OSC's. It has the advantages of both organic and inorganic materials and thus can be considered as an ideal material for encapsulation of organic solar cells.

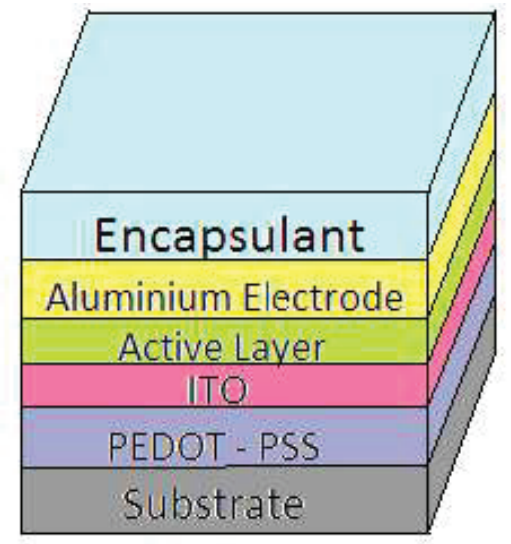

Figure 1: Layers of an organic solar cell

\section{References}

1. Sindhu Seethamraju, PC Ramamurthy, and Giridhar Springer, Encapsulation for Improving the Efficiency of Solar Cell.

2. Lewis, J.S., Material Challenges for Flexible organic devices, materials today, 2006. 9(1) p. 3845.

3. W. J. Potscavage, S.Yoo, B. Domercq, and B. Kippelen Encapsulation of pentacene/C60 organic solar cells with $\mathrm{Al}_{2} \mathrm{O}_{3}$ deposited by atomic layer deposition. 